DOI https://doi.org/10.30525/978-9934-26-113-8-24

\title{
FEATURES OF RECOVERY AND DISSECTION OF UPPER EXTREMITY
}

\author{
Lyutenko M. A. \\ Assistant Professor at the Department of Human Anatomy \\ Kharkiv National Medical University \\ Vovk O. Yu. \\ Doctor of Medical Sciences, Professor, \\ Head of the Department of Human Anatomy \\ Kharkiv National Medical University \\ Korobchanska A. B. \\ Candidate of Medical Sciences, \\ Associate Professor at the department of human anatomy \\ Kharkiv National Medical University \\ Sachenko D. V. \\ Student \\ Kharkiv National Medical University
}

\author{
Abuzeineh R. F. \\ Student \\ Kharkiv National Medical University \\ Kharkiv, Ukraine.
}

Introduction: The feature of the training sessions at the department of anatomy in medical schools is the use of natural anatomical specimens in practical classes, in the lecture course, as well as for students to perform independent and individual scientific work, in addition, to replenish exposition of educational anatomical museum. In the conditions of acute shortage of corpse material we carried out restoration and dissection of upper extremity of an adult. After a long time of specimen in a solution of formalin, all soft tissues were strongly compacted, fingers were in a bent position. In the specimen were partially isolated muscles and neuro-vascular bundles on the front of shoulder, forearm and hand. To improve the informativeness and clarity of specimen of upper extremity, preliminary preparation for further 
preparation was carried out. In the area of hand and fingers was fixed a special device for dissecting the human hand, according to a patent for a utility model - UA108446, developed at the Department of Human Anatomy of KhNMU. The aim of this work is to improve the methods of restoration of wet museum specimens and the practicing of skills in the preparation of muscles, vessels and nerves of upper extremity.

Materials and methods: To perform this work, classical preparation methods were used. For soften soft tissues and neutralize formalin in them, specimen was placed in a glass container with a $3 \%$ solution of ammonia and hydrogen peroxide 1:1, for 7 days. To restore the visibility of blood vessels and nerves, method of surface staining with red and blue gouache and method of placing strips of black tissue under nerve bundles, followed by coating with $5 \%$ gelatin solution, was used. In the grooves, muscles were spread with a ligature and special pins made of inert metal. The material of our work was a specimen of upper extremity of an adult from the funds of museum of the Department of Human Anatomy, KhNMU.

Course of work: Specimen of upper extremity of an adult was originally in the exposition of educational museum of the Department of Human Anatomy of KhNMU. Due to the depressurization of the container, which contained specimen in $10 \%$ formalin solution, it was taken for restoration. During the restoration work we found that specimen was prepared only anterior surface of muscles of the shoulder, forearm and partially hand with some vessels and nerves. It was decided to expand the visibility of specimen. For this purpose, possible areas of preparation of posterior and partially anterior surface of human upper limb (muscles, fascia, neurovascular bundles) were identified. Then specimen was washed with running water and placed in a container with a $3 \%$ solution of ammonia and hydrogen peroxide 1:1 to soften and neutralize formalin. The wrist and fingers were straightened using a device for dissecting a human hand developed at the Department of Human Anatomy, KhNMU. After preliminary training, we began to prepare selected areas of upper extremity. Skin incisions were made gradually, first on the shoulder, then on the forearm, hand and fingers of the upper limb. After removing the skin, we dissected the fascia and gained access to the muscles. During the preparation of posterior surface of the forearm, we removed our own fascia of the forearm, leaving a fragment of fascia on the posterior surface in the lower third of body of the forearm, where it looks like a tendon plate. After removing fascia, superficial and deep layers of posterior group of forearm muscles were dissected. Next, dissect muscles of anterior surface of the forearm, which belong to the group of flexors and form four layers. To dissect flexor tendons on the hands and fingers, we pre-dissected their synovial 
sacs in the carpal tunnel and on the palm, and synovial vaginas on the fingers. Next, tendons of superficial and deep flexors of fingers and long flexor of the thumb in the carpal tunnel, palm and fingers are prepared. There are four worm-shaped muscles and three palmar interosseous muscles in the palm area. Subsequently, muscles of raising the thumb and muscles of raising the little finger are dissected. During the preparation of muscles and fascia, we detected and dissected vessels and nerves of anterior and posterior surfaces of upper extremity. Vessels were superficially painted with gouache paints. Arteries are red and veins are blue. Strips of black paper were placed under the nerve branches for greater contrast. Along the grooves of shoulder and forearm muscles were partially pulled with a ligature and special pins made of inert metal. This made it possible to better demonstrate course and location of neurovascular bundles. Fragments of their own, superficial fascia and some branches of skin vessels and nerves were left in fragments. After completion of all work, specimen of human upper extremity, using a soft brush, was covered with a thin layer of 5\% gelatin. This fixed a layer of paint on the vessels and, under the nerve trunks, paper strips. The specimen was placed in a glass container (jar) of rectangular shape with a height of $1000 \mathrm{~mm}$ and a wall width of $200 \mathrm{~mm}$ with lid. On the inner surface of the lid, in the middle of it, was glued, using aquarium silicone, a glass tube $100 \mathrm{~mm}$ long and $5 \mathrm{~mm}$ in diameter. A fishing line was passed through it, with the help of which specimen of upper limb was hung inside the jar. Free ends of line were passed through the area of humeral head and brought together by knots. The specimen was immersed in a jar pre-filled with a solution of $10 \%$ formalin, according to the level of corresponding displaced volume of liquid when immersed. At the top edge of the jars was set aquarium silicone sealant transparent color Akfix $100 \mathrm{AQ}$ and, at the time of immersion of specimen, lid was installed on the upper surface of jar and glued with sealant.

Conclusion: Thus, having carried out work on the restoration and expansion of specimen of upper extremity, using above methods, specimen was returned to the museum of the Department of Human Anatomy KhNMU in an updated and more informative state. This is very valuable today in the conditions of impossibility of receipt of fresh corpse material for scientific and educational purposes on studying of anatomy. Method of dissection of human upper extremity developed by us, also, can be applied and at dissection of corpse material for practical employment. And the device developed by us, for preparation of hand, makes it possible to reveal greater access to the anatomical formations of hand and fingers, especially their palmar surface. 


\section{References:}

1. Пикалюк В. С., Мороз Г. А., Кутя С. А. Методическое пособие по изготовлению анатомических препаратов. Симферополь, 2004. 76 с.

2. Дорохович Г. П., Богданова М. И. Музейное дело: учеб.- метод. пособие. Минск: БГМУ, 2015. 20 с.

3. Никульченко Е. Ф. Методика топографо-анатомического препарирования (в помощь студентам при практических занятиях). КГМИ. Курс. книжн. изд-во, 1960. 163 с.

4. Привес М. Г. Методы консервации анатомических препаратов. Л.:Медгиз, 1956. 128 с.

5. Ярославец Б. М. Анатомическая техника: руководство по изготовлению анатомических и биологических препаратов. Фрунзе: Изд-во Киргиз. гос. ун-та, 1961. 444 с.

6. Бальзамирование и реставрация трупов: Руководство / Кузнецов Л. Е., Хохлов В. В., Федосеев С. П., Шигаев В. Б. М.: Медицина, 1999. $496 \mathrm{c}$.

7. Гайворонский И. В., Ничипорук Г. И. Клиническая анатомия сосудов и нервов: учебное пособие. 6-е изд. Санкт-Петербург: Элби-спб, 2009. 144 с.

8. Тонков В. Н. Пособие к практическому изучению сосудов и нервов человека. 6- е изд., Испр. и доп. Л.: Медгиз, 1956. 119 с.

9. Liselotte hermes da fonseca. Verfbhrerische verfall. «kurperwelten» als geselschaftliches schlbsselereignis / f. Da h. Liselotte, K.Thoms. lengrerich, Ber-lin, Bremen, Miami, Riga, Vierheim, Wien, Zagreb: Pabst science publischers, 2007. $445 \mathrm{~s}$. 